\title{
STRUKTUR BISNIS KLASTER RUMPUT LAUT GORONTALO
}

\author{
Oleh: \\ Armen Zulham dan Tenny Apriliani *
}

\begin{abstract}
ABSTRAK
Bisnis rumput laut di Gorontalo memberi multiplier effect penting untuk masyarakat pesisir didaerah itu. Tujuan dari kajian ini adalah untuk memberi masukan tentang arah pengembangan bisnis rumput laut di Gorontalo. Penelitian dilakukan dengan tehnik Rural Rapid Appraisal, melalui wawancara dengan stakeholder pada beberapa desa di Kabupaten Gorontalo Utara dan Kabupaten Boalemo. Hasil penelitian menunjukkan tidak seluruh perairan Laut Sulawesi dan Teluk Tomini di Gorontalo sesuai sebagai lokasi budidaya rumput laut. Bisnis rumput laut di Gorontalo memerlukan penataan ruang dan kelembagaan untuk menghindari konflik dimasa depan, karena budidaya rumput laut hanya berkembang pada lokasi tertentu dan suplai rumput laut hanya diserap oleh dua pedagang besar. Rumput laut yang diperdagangkan adalah jenis Euchema cottonii. Posisi pembudidaya rumput laut cukup baik dalam mata rantai bisnis rumput laut ini. Rumput laut yang dikumpulkan oleh pedagang besar tersebut diperkirakan sekitar 70 persen dikirim ke Surabaya dan sisanya dikirim Manado. Total margin pemasaran terhadap harga di Surabaya dan Manado masing-masing masing-masing berkisar antara $(0,130,25)$ dan $(0,10 \quad 0,22)$. Angka tersebut menunjukkan: pertama saat ini persaingan antar dua pedagang besar tersebut sangat kecil, kedua pengiriman rumput laut ke Surabaya lebih menarik dibandingkan mengirim rumput laut ke Manado. Pedagang besar merupakan core utama pengembangan klaster tersebut. Jika pemerintah melakukan upaya mendirikan industri SRC (Semi Refines Carragenan) di Gorontalo, tanpa mempertimbangkan peran pedagang itu maka upaya tersebut dapat merusak tatanan rantai pemasaran dan industri SRC itu sulit memperoleh bahan baku.
\end{abstract}

\section{Keywords : Rumput Laut, klaster, pemasaran, bisnis, Gorontalo.}

\section{Abstract : Business Structure of Seaweed Cluster in Gorontalo by Armen Zulham and Tenny Apriliani}

Seaweed business in Gorontalo grows gradually and drives an important multiplier effect for local costal communities. The purpose of this study was to give the alternative suggestion concerning the direction of sea weeds business in Gorontalo. Research was conducted using Rural Rapid Appraisal technique, through the interview with stakeholders involved in sea weed business in several villages in North Gorontalo, and Boalemo districts of Gorontalo. The research finding indicated: only a limited space of coastal sea areas of the Sulawesi Sea and Tomini Bay can be use as a location of sea weed culture activities. The sea weed business in Gorontalo need to manage the cultivated area and institutions improvement to eliminate the future conflict, due to local sea weed demanded only by two biggest traders in Kwandang. Only Euchema cottonii dried traded and the bulk of dried sea weed distributed to Surabaya 70 percent and the rest traded to Manado. Total marketing margin of dried sea weed comparing to Surabaya and Manado prices are $(0,13 \quad 0,25)$ and $(0,10 \quad 0,22)$. The values indicated: first there relatively small conflict between 2 wholesalers to collect dried sea weed. Second, Surabaya market more interested comparing Manado market in sea weed trade. If the Government plan to build the SRC industry in Gorontalo with no involvement of the 2 traders, the industry will be collapse within a year due to sea weed raw material shortage.

\section{Keywords : Seaweed, Cluster, Marketing, Business and Gorontalo.}

\footnotetext{
* Peneliti Pada Balai Besar Riset Sosial Ekonomi Kelautan dan Perikanan, BRKP-DKP. JI. KS TUBUN Petamburan VI Slipi Jakarta 10260. Telp. (021) 53650162
} 


\section{PENDAHULUAN}

Gorontalo merupakan salah satu provinsi yang menjadikan rumput laut sebagai komoditas unggulan. Saat ini bisnis rumput laut mulai berkembang pada beberapa desa di Gorontalo, seiring dengan pencanangan Gerakan Menanam Rumput Laut (GEMAR LAUT) pada tahun 2006. Jenis rumput laut yang berkembang adalah Euchema cottonii.

Sejarah awal perkembangan rumput laut didaerah ini tidak tercatat dengan baik. Informasi masyarakat di desa Limbatihu Kecamatan Penguyaman Pantai, desa Bajo Kecamatan Tilamuta (Kab. Boalemo) dan Kwandang (Kab. Gorontalo Utara) menunjukkan rumput laut di desa itu diperkenalkan oleh pedagang pada tahun 2000 sampai 2002. Di desa Bubaa pada Kecamatan Panguyaman Pantai budidaya rumput laut dilakukan oleh murid Sekolah Kejuruan setempat. Dengan harapan hasil panen rumput laut itu dijual kepada pedagang.

Sebagai sentra pengembangan baru maka diperlukan strategi untuk mengembangkan bisnis rumput laut tersebut. Saat ini wacana pengembangan rumput laut di Gorontalo mengarah pada klaster. Wacana pengembangan klaster rumput laut didasarkan pada keberhasilan klaster industri, yang diperkenalkan oleh Porter (1990) dalam tulisan the Competitive Advantages of Nations, melalui model yang disebut "diamond of advantage". Klaster tersebut menurut Humprey \& Schmitz (1995), dimanfaatkan sebagai strategi pengembangan wilayah untuk meningkatkan manfaat potensi ekonomi pada wilayah itu, melalui social engineering.

Pada wilayah pengembangan klaster tersebut, investasi yang ada diharapkan dapat berfungsi secara efisien, tepat guna dan mampu mendorong pertumbuhan ekonomi lokal maupun nasional secara maksimal. Hal ini dapat terjadi jika investasi yang telah dan akan ditanamkan pada sentra industri perikanan dapat diarahkan untuk memfasilitasi terjalinnya kerjasama yang optimal antar unit usaha dalam klaster, sehingga secara kumulatif kinerja dari sentra tersebut dapat meningkat. Komunitas klaster perikanan tersebut meliputi para pelaku bisnis, baik yang berusaha pada sektor hulu maupun hilir, dan lembaga pendukung lainnya.

Tujuan dari tulisan ini adalah: pertama, mempelajari karakteristik bisnis rumput laut terkait dengan pengembangan klaster. Kedua, mempelajari relasi unit usaha dalam pengembangan klaster rumput laut. Ketiga, merumuskan alternatif bentuk klaster rumput laut Gorontalo.

\section{METODE}

\section{Lokasi Penelitian}

Penelitian ini dilakukan pada bulan Juni 2007 di Kabupaten Gorontalo Utara (Kecamatan Kwandang, desa Ponelo) dan Kabupaten Boalemo (Kecamatan Panguyaman Pantai: desa Bubaa, dan desa Limbatihu; Kecamatan Tilamuta: desa Bajo, desa Pentadu Barat dan Modelomo). Kabupaten yang pertama merupakan wilayah pengembangan yang berada pada laut Sulawesi, sedangkan Kabupaten yang kedua merupakan salah satu wilayah pengembangan di wilayah laut Teluk Tomini. Lokasi contoh tersebut, merupakan wilayah sasaran pengembangan klaster rumput laut.

\section{Metode Pengumpulan dan Analisis Data}

Penelitian dilakukan dengan tehnik Rural Rapid Appraisal (RRA). Data yang dikumpulkan merupakan data sekunder dan data primer. Data sekunder meliputi data potensi dari komoditas yang diteliti, dan kebijakan daerah terhadap pengembangan komoditas tersebut. Sementara itu, data primer yang dikumpulkan meliputi biaya produksi dan biaya pemasaran, jaringan pemasaran serta kendala-kendala dalam pengembangan komoditas tersebut.

Responden yang diwawancara dapat dikelompokkan menjadi: pejabat pemerintah 
(Dinas Perikanan dan Kelautan Provinsi dan Kabupaten 4 responden), pembudidaya rumput laut (15 responden), pedagang pengumpul (10 responden), pengolah dan pedagang besar (2 responden), pengusaha penyedia jasa distribusi barang (1 responden), tokoh masyarakat (4 responden)

Secara umum pendekatan penelitian ini adalah pendekatan eksploratif yang menjelaskan fenomena lapangan. Data yang diperoleh ditampilkan dalam bentuk tabeltabel analisis. Data tersebut dianalisis secara deskriptif untuk menjelaskan berbagai karakterstik dan fenomena yang terkait dengan pengembangan klaster tersebut.

\section{HASIL DAN PEMBAHASAN}

\section{Usaha Rumput Laut dalam Ekonomi Desa Pesisir Gorontalo}

Peran rumput laut dalam perekonomian pesisir Gorontalo saat ini masih terbatas pada usaha menghasilkan bahan mentah. Sebagai komoditas komersial, bisnis ini pada tingkat desa masih dalam bentuk bisnis rumah tangga. Perlu dicatat, budidaya rumput laut itu tidak dapat dilakukan pada semua perairan di desa pesisir Gorontalo. Oleh sebab itu, kegagalan usaha budidaya sering terjadi pada desa-desa pesisir di perairan Teluk Tomini. Namun, bisnis rumput laut tersebut memberikan mutilplier effect penting pada masyarakat, terutama sebagai sumber pendapatan baru masyarakat desa, dan menyediakan lapangan kerja baru.

Saat ini usaha budidaya rumput laut di Gorontalo belum berkembang seperti yang diharapkan. Hal ini disebabkan karena keterbatasan tenaga kerja, sehingga usaha budidaya rumput laut tersebut kurang terawat dengan baik. Sebagai suatu peluang ekonomi maka usaha budidaya rumput laut di perairan Gorontalo ini memerlukan penataan ruang budidaya yang baik, untuk menghindari konflik dalam pemanfaatan ruang perairan dimasa depan. Oleh sebab itu, peran pemerintah sebagai regulator sangat penting dalam pengembangan bisnis ini.

Berkaitan dengan hal tersebut, diperlukan strategi dalam membangun bisnis rumput laut dari hulu sampai hilir di daerah ini, apalagi di Gorontalo belum terdapat industri yang mengolah bahan mentah menjadi barang setengah jadi. Peran pedagang besar sangat dominan untuk mendistribusikan rumput laut. Oleh sebab itu jika pemerintah berupaya ikut membangun bisnis tersebut maka peran itu, jangan menjadi pesaing pengusaha atau pedagang. Pemerintah perlu membuat kebijakan untuk memberi insentif kepada pengusaha agar mengembangkan industri di daerah tersebut.

\section{Potensi Budidaya Rumput Laut}

Potensi budidaya rumput laut di wilayah perairan Laut Sulawesi berkembang di Kabupaten Gorontalo Utara (Kecamatan Kwandang dan Kecamatan Anggrek), sedangkan di Teluk Tomini terdapat di Kabupaten Pahuwato, dan Kabupaten Boalemo.

Tabel 1, memberi gambaran tentang potensi areal perairan yang dapat digunakan untuk budidaya rumput laut. Data tersebut merupakan data jumlah potensi luas areal per desa pada setiap Kecamatan di Provinsi Gorontalo. Potensi perairan yang dapat dimanfaatkan untuk budidaya rumput laut sekitar 14.150 hektar, dari jumlah tersebut yang baru dimanfaatkan sekitar 830 hektar (sekitar 6 persen).

Hasil wawancara dengan masyarakat setempat menunjukkan tidak semua desa di sepanjang pesisir Teluk Tomini dan Laut Sulawesi sesuai untuk pengembangan rumput laut, karena sifat oceanografis perairan. Pada daerah yang gelombang laut kuat, sering terjadi up welling atau banyak muara sungai maka rumput laut sulit tumbuh dengan sempurna. Pada wilayah perairan dengan kondisi yang demikian rumput laut akan terkena penyakit ice-ice, yang menyebabkan rumput laut tersebut akan patah dan membusuk. Kondisi budidaya yang demikian 
Tabel 1. Potensi Areal Budidaya Rumput Laut di Provinsi Gorontalo, 2007

Table 1. Sea Weed Potential Area in Gorontalo Province, 2007

\begin{tabular}{|c|c|c|c|c|}
\hline $\begin{array}{c}\text { Kabupaten / } \\
\text { District }\end{array}$ & $\begin{array}{l}\text { Kecamatan / } \\
\text { Sub- District }\end{array}$ & $\begin{array}{c}\text { Potensi Areal } \\
\text { (Ha) / } \\
\text { Potential } \\
\text { Area (Ha) }\end{array}$ & $\begin{array}{c}\text { Areal yang } \\
\text { dimanfaatkan } \\
\text { (Ha) / } \\
\text { Utilization Area } \\
\text { (Ha) }\end{array}$ & $\begin{array}{c}\text { Potensi Areal } \\
\text { yang tersedia } \\
(\%) / \\
\text { Available } \\
\text { Potential Area } \\
(\%)\end{array}$ \\
\hline \multirow[t]{3}{*}{ Pahuwato } & Lemito & 3.000 & 194,5 & 93,52 \\
\hline & Popayato & 2.500 & 193 & 92,28 \\
\hline & Paguat & 1.100 & 16 & 98,55 \\
\hline \multirow[t]{5}{*}{ Boalemo } & $\begin{array}{l}\text { Tilamuta } \\
\text { Panquyaman }\end{array}$ & 700 & 27,3 & 96,10 \\
\hline & Pantai & 300 & 38 & 87,33 \\
\hline & Dulupi & 200 & 20 & 90,00 \\
\hline & Batumoito & 700 & 42,4 & 93,94 \\
\hline & Mananggu & 400 & 13 & 96,75 \\
\hline \multicolumn{5}{|l|}{ Gorontalo } \\
\hline \multirow[t]{4}{*}{ Utara } & Kwandang & 1.500 & 81,3 & 94,58 \\
\hline & Anggrek & 2.820 & 164 & 94,18 \\
\hline & Atinggola & 130 & 10 & 92,31 \\
\hline & Sumalata & 300 & 10 & 96,67 \\
\hline \multirow[t]{3}{*}{ Bone Bolango } & Kabila Bone & 50 & 9 & 82,00 \\
\hline & Bone Pantai & 30 & 4 & 86,67 \\
\hline & Bone Raya & 20 & 1 & 95,00 \\
\hline \multirow[t]{2}{*}{ Kab. Gorontalo } & Batudaa Pantai & 200 & 2,25 & 98,88 \\
\hline & Boliyohuto & 150 & 3,5 & 97,67 \\
\hline \multirow[t]{2}{*}{ Kota Gorontalo } & Pohe & 20 & 0,25 & 98,75 \\
\hline & Kota Timur & 30 & 0,25 & 99,17 \\
\hline Prov. Gorontalo & - & 14.150 & 829,75 & 94,14 \\
\hline
\end{tabular}

Sumber: Dinas Kelautan dan Perikanan Prov. Gorontalo, (Mei 2007)

Source: Marine and Fisheries Agency of Gorontalo Province (Mei 2007).

banyak ditemui di wilayah perairan teluk Tomini, terutama pada perairan teluk dengan cekungan yang sempit. Oleh sebab itu untuk menentukan lokasi budidaya rumput laut yang sesuai perlu mempertimbangkan kondisi fisika dan kimia perairan (terutama salinitas) dan akses ke lokasi budidaya tersebut, serta ketersediaan tenaga kerja.

\section{Karakteristik Pelaku Usaha}

Pembibitan Rumput Laut

Usaha khusus sebagai penyedia bibit rumput laut belum berkembang, pembelian bibit rumput laut dilakukan, karena pola tanam rumput laut yang dilaksanakan pembudidaya adalah panen total. Pola panen total seperti ini mengakibatkan setiap kali musim tanam 
pembudidaya rumput laut harus membeli bibit rumput laut dari pembudidaya rumput laut lain umumnya dari desa lain dengan harga ratarata Rp. 1.000,-/kg. Pembelian bibit dari perairan lain ini dimaksudkan agar rumput laut tersebut dapat tumbuh lebih baik dibandingkan dengan bibit pembudidaya dari perairan yang sama.

Untuk memenuhi kebutuhan bibit rumput laut saat ini sedang diujicoba pengembangan kebun bibit oleh Dinas Perikanan dan Kelautan Propinsi Gorontalo melalui kelompok Taksi Mina Bahari (TMB) Kecamatan Kwandang. Diperkirakan untuk mensuplai kebutuhan bibit rumput laut pada pengembangan usaha budidaya rumput laut seluas $2.561 \mathrm{Ha}$ diperlukan pengembangan kebun bibit seluas $\pm 213 \mathrm{Ha}$ dengan target produksi rumput laut basah 68 ton/Ha/tahun.

Pembinaan pola tanam juga dilakukan oleh TMB sebagai upaya mendorong pembudidaya menyediakan bibit. Pola yang diujicoba adalah: dari 10 tali ris hanya 8 tali ris yang diikat rumput laut. Setelah rumput laut berumur 30 hari, rumput laut pada 2 tali ris dipotong dan digunakan sebagai bibit pada 2 tali ris yang tersisa. Pada umur 45 hari rumput laut dari 6 tali ris dipanen, kemudian bibit dari
2 tali ris dipindah ke sisa tali ris yang dipanen. Upaya ini terus disosialisasikan agar pembudidaya dapat menyediakan bibit rumput laut sendiri dan tidak harus membeli.

\section{Pembudidaya Rumput Laut}

Metode budidaya rumput laut yang digunakan oleh pembudidaya rumput laut adalah metoda long line, masyarakat setempat menyebutnya metoda "tali panjang". Ukuran luasan budidaya rumput laut per longline yang digunakan oleh pembudidaya berbeda disetiap lokasi. Di Kecamatan Kwandang pembudidaya umumnya menggunakan ukuran longline $(50 \times 50) \mathrm{m}$ setara dengan 100 tali ris, di Kecamatan Paguyaman Pantai menggunakan ukuran longline $(40 \times 50) \mathrm{m}$ dengan jumlah tali ris 40 buah, dan ukuran $(50 \times 100)$ m dengan 100 tali ris. Investasi yang dibutuhkan untuk memulai usaha budidaya rumput laut bervariasi, untuk longline ukuran $(50 \times 50) \mathrm{m}$ investasi yang diperlukan sekitar Rp. 9 juta, sedangkan untuk ukuran $(40 \times 50)$ m adalah sekitar Rp. 5 juta.

Perkiraan kebutuhan biaya investasi maupun biaya produksi untuk budidaya rumput laut ukuran longline $(50 \times 50)$ m 100 tali ris dapat dipelajari pada Tabel 2.

Tabel2. Rata-rata Biaya Investasi, Biaya Produksi dan Pendapatan dari Budidaya Rumput Laut Jenis E.cotonii per Siklus Produksi di Desa Ponelo, Kecamatan Kwandang, Kabupaten Gorontalo Utara, 2007

Table 2. Avarage Investment Cost, Production Cost and Revenue From E. Cotonii Sea Weed Culture per Production Cycle in Ponelo Vilage, Kwandang Sub District North Gorontalo District, 2007

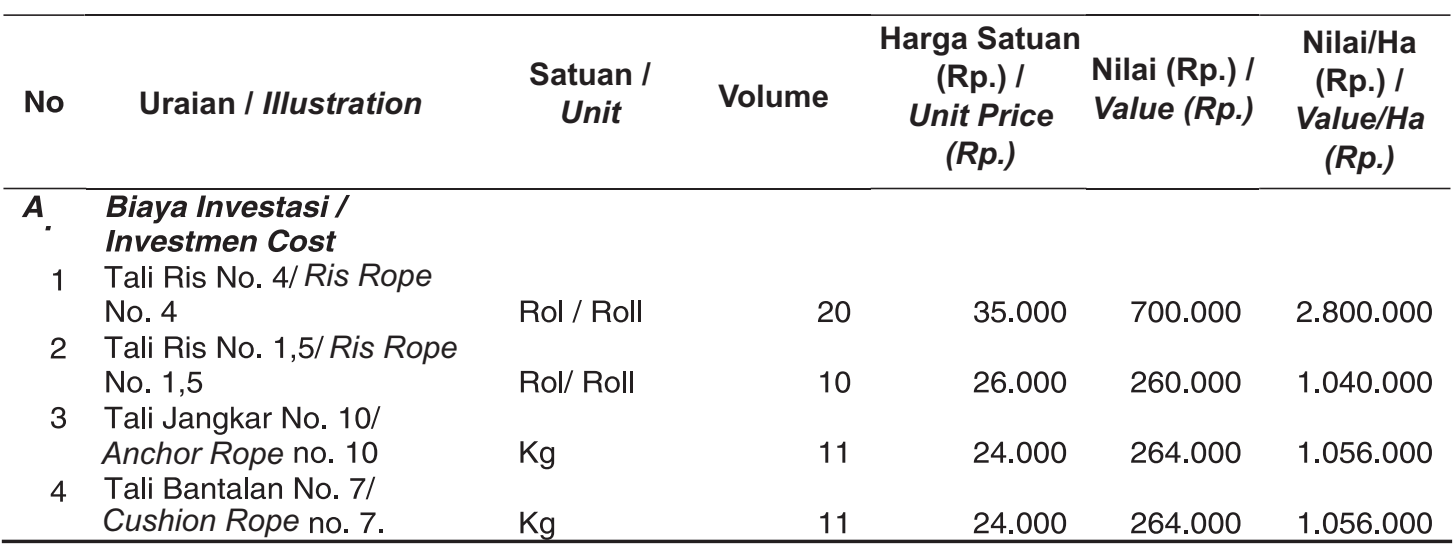


Lanjutan Tabel 2

\begin{tabular}{|c|c|c|c|c|c|c|}
\hline No & Uraian / IIlustration & $\begin{array}{c}\text { Satuan I } \\
\text { Unit }\end{array}$ & Volume & $\begin{array}{l}\text { Harga Satuan } \\
\text { (Rp.) I } \\
\text { Unit Price } \\
\text { (Rp.) }\end{array}$ & $\begin{array}{l}\text { Nilai (Rp.) I } \\
\text { Value (Rp.) }\end{array}$ & $\begin{array}{l}\text { Nilai/Ha } \\
\text { (Rp.)/ } \\
\text { Value/Ha } \\
\text { (Rp.) }\end{array}$ \\
\hline 5 & $\begin{array}{l}\text { Pelampung Botol Aqua/ } \\
\text { Aqua Bottle Float }\end{array}$ & $\begin{array}{l}\text { Botol/ } \\
\text { Bottle }\end{array}$ & 1.500 & 500 & 750.000 & 3.000 .000 \\
\hline 6 & $\begin{array}{l}\text { Jangkar Induk (karung)/ } \\
\text { Main Anchor (Sack) }\end{array}$ & $\begin{array}{l}\text { Lembar/ } \\
\text { Sheet }\end{array}$ & 28 & 2.500 & 70.000 & 280.000 \\
\hline 7 & $\begin{array}{l}\text { Jangkar Samping (karung)/ } \\
\text { Side Anchor (Sack) }\end{array}$ & $\begin{array}{l}\text { Lembar/ } \\
\text { Sheet }\end{array}$ & 8 & 2.500 & 20.000 & 80.000 \\
\hline 8 & $\begin{array}{l}\text { Pelampung Sudut } \\
\text { (Sterofom) / Corner Float }\end{array}$ & $\begin{array}{l}\text { Buah/ } \\
\text { Unit }\end{array}$ & 4 & 125.000 & 500.000 & 2.000 .000 \\
\hline \multirow[t]{2}{*}{9} & $\begin{array}{l}\text { Pembuatan bantalan } \\
\text { Longline / Longline Cushion }\end{array}$ & $\begin{array}{l}\text { Paket / } \\
\text { Package }\end{array}$ & & & & \\
\hline & Fee & & 1 & 600.000 & 600.000 & 2.400 .000 \\
\hline 10 & $\begin{array}{l}\text { Perahu / Canoe } \\
\text { Total Biaya Investasi/ Total } \\
\text { Investment Cost }\end{array}$ & $\begin{array}{l}\text { Buah/ } \\
\text { Unit }\end{array}$ & 1 & 5.500 .000 & $\begin{array}{l}5.500 .000 \\
8.928 .000\end{array}$ & $\begin{array}{r}5.500 .000 \\
19.212 .000\end{array}$ \\
\hline $\begin{array}{l}\text { B. } \\
1\end{array}$ & $\begin{array}{l}\text { Biaya Operasional/ } \\
\text { Operational Cost } \\
\text { Bibit Rumput Laut/Sea }\end{array}$ & & & & & \\
\hline 2 & $\begin{array}{l}\text { Weed Seed } \\
\text { Upah pasang cincin dan } \\
\text { bibit/ Ring and Seed Setting }\end{array}$ & 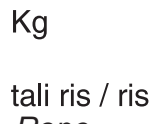 & 325 & 1.000 & 325.000 & 1.300 .000 \\
\hline 3 & $\begin{array}{l}\text { Fee } \\
\text { Pemeliharaan ( } 5 \text { minggu } x \\
10 \text { lt)/ Maintenance ( } 5\end{array}$ & & 100 & 2.500 & 250.000 & 1.000 .000 \\
\hline \multirow{3}{*}{4} & $\begin{array}{l}\text { Weeks } \times 10 \text { It } \\
\text { Upah Panen/Harvesting }\end{array}$ & $\begin{array}{l}\text { Liter } \\
\text { Tali Ris/ }\end{array}$ & 50 & 5.000 & 250.000 & 1.000 .000 \\
\hline & Cost & Ris Rope & 100 & 2.000 & 200.000 & 800.000 \\
\hline & $\begin{array}{l}\text { Total Biaya Operasional / } \\
\text { Total Operational Cost }\end{array}$ & & & & 1.025 .000 & 4.100 .000 \\
\hline C. & $\begin{array}{l}\text { Produksi / Production } \\
\text { Rumput Laut Basah / Wet } \\
\text { Sea Weed }\end{array}$ & $\mathrm{Kg}$ & 2.500 & 1.000 & 2.500 .000 & 10.000 .000 \\
\hline 2 & $\begin{array}{l}\text { Rumput Laut Kering/Dry } \\
\text { Sea Weed }\end{array}$ & $\mathrm{Kg}$ & 1.000 & 4.800 & 4.800 .000 & 19.200 .000 \\
\hline
\end{tabular}

Sumber: Data Primer (Diolah), 2007 / Primary Data (Processed), 2007

Keterangan: Ukuran Budidaya $(50 \times 50) m$ - 100 tali ris. / Culture Media Size $(50 \times 50) m$ - 100 Ris Rope

Selama satu tahun pembudidaya dapat membudidayakan rumput laut antara 5 sampai 6 siklus produksi. Investasi yang cukup besar adalah untuk penyediaan perahu, tali dan pelampung.

Produksi rumput laut yang dihasilkan pembudidaya pada umumnya dijual dalam bentuk rumput laut kering. Pada lokasi di desa
Bajo dan Limbatihu terdapat pembudidaya yang menjual rumput laut dalam bentuk segar basah, jumlah pembudidaya ini hanya sedikit. Pilihan untuk menjual rumput laut dalam bentuk kering, karena harga jualnya yang lebih jauh lebih tinggi dibandingkan dijual basah. Harga rumput laut basah berkisar antara Rp. 300 s/d Rp. 1.000/kg, sedangkan 
jika dijual dalam bentuk kering harganya mencapai Rp. 4.000 s/d Rp. 4.800/kg. Harga rumput laut umumnya rendah terjadi pada daerah yang akses pemasarannya sulit, sedangkan pada lokasi dengan akses pemasaran yang baik harga rumput laut yang diterima pembudidaya cenderung relatif baik.

Rumput laut E.cotonii yang telah dikeringkan oleh pembudidaya umumnya kadar air berkisar antara: $30-35 \%$. Rendemen rumput laut dari basah menjadi kering bervariasi dari $7: 1$ sampai $10: 1$. Pada kasus yang terakhir konversi tersebut menunjukkan dari rumput laut basah sebanyak $100 \mathrm{~kg}$, maka setelah dikeringkan akan menjadi $10 \mathrm{~kg}$ rumput laut kering.

\section{Pedagang}

\section{Pedagang Pengumpul Desa}

Pedagang pengumpul desa berfungsi membeli rumput laut kering dari pembudidaya di sekitar desa atau desa tetangga. Jumlah pedagang pengumpul desa pada setiap lokasi berkisar 1-2 orang. Harga beli rumput laut ditingkat pedagang pengumpul desa terdiri dari dua harga, pada lokasi budidaya yang akses transportasi kurang memadai umumnya harga beli pedagang pengumpul pada pembudidaya lebih rendah, sedangkan pada lokasi budidaya yang akses transportasi lebih baik maka harga yang diterima pembudidaya lebih tinggi.

Untuk memperoleh rumput laut pedagang pengumpul desa umumnya memberi modal usaha kepada pembudidaya rumput laut atau membantu membiayai kebutuhan hidup sehari-hari pembudidaya rumput laut. Dengan cara yang demikian maka pembudidaya rumput laut harus menjual hasil panen rumput laut kepada pedagang pengumpul desa. Pedagang pengumpul desa akan memperhitungkan nilai hasil panen dengan pengeluaran yang dikeluarkan pedagang kepada pembudidaya rumput laut. Kekurangan pembayaran biasanya dibayar tunai oleh pedagang pengumpul desa. Pada saat itu pedagang pengumpul desa memberikan pinjaman modal untuk pembudidaya.

\section{Pedagang Kecamatan}

Pedagang kecamatan ini hanya terdapat di Kecamatan Dulupi. Pedagang kecamatan ini menerima rumput laut dari pedagang pengupul desa di pasar kecamatan. Pedagang kecamatan ini merupakan pedagang yang membeli hasil petanian, jadi bukan pedagang yang khusus membeli rumput laut.

Pedagang kecamatan ini menerima juga rumput laut kering yang dijual petani. dan pedagang ini sangat membantu memasarkan rumput laut dari desa-desa dengan akses transportasi darat yang sulit terutama dari desa-desa di sekitar Teluk Tomini. Rumput laut yang telah terkumpul pada pedagang kecamatan akan diambil oleh pedagang besar jika volumenya telah mencapai lebih dari 1 ton.

\section{Pedagang Besar}

Pedagang besar adalah para pedagang yang membeli rumput laut dari pedagang pengumpul ditingkat desa maupun pedagang pengumpul tingkat kecamatan. Berdasarkan hasil survey diperoleh informasi bahwa hanya terdapat 2 pedagang besar di Gorontalo dan pedagang tersebut berada di Kecamatan Kwandang Kabupaten Gorontalo Utara.

Pedagang besar yang pertama merupakan perwakilan dari perusahaan pengolahan rumput laut di Surabaya yaitu: PT. Amarta Carragenan Indonesia (PT. ACI), sedangkan pedagang besar yang kedua adalah perwakilan dari PT. Sumber Nelayan Manado.

Biaya pengiriman barang dari Gorontalo ke Surabaya dan Manado ditanggung oleh perusahaan tersebut. Pengiriman ke Surabaya menggunakan kontainer melalui pelabuhan Anggrek. Setiap kali pengiriman ke Surabaya menggunakan kontainer dengan minimal pengiriman 15 ton ( \pm 250 karung @ 60 $\mathrm{kg})$. Sementara pengiriman ke Manado 
dengan truk. Biaya pengiriman rumput laut per kontainer dari Gorontalo ke Surabaya sekitar Rp. 6,5 juta, sedangkan biaya pengirimam rumput laut dari Gorotalo ke Manado Rp. 1,5 juta per truk. Rumput laut sekitar 70 persen dikirim ke Surabaya dan sisanya dikirim pedagang besar ke Manado.

Aktivitas pedagang besar tersebut menyerap tenaga kerja untuk pengepakan dan bongkar muat. Tenaga kerja yang diperkerjakan oleh pedagang besar di Kecamatan Kwandang terdiri dari tenaga kerja tetap dan tenaga harian lepas. Tenaga kerja tetap terdiri dari 4 orang yang bertugas untuk menjaga dan mengawasi gudang serta menerima rumput laut dari pedagang pengumpul. Jumlah tenaga harian lepas tergantung pada jumlah rumput laut diperoleh, rata-rata penggunaan tenaga harian lepas adalah 1520 orang dan upah mereka adalah Rp. 1.250/karung.

Pada penjualan rumput laut pedagang pengumpul akan memperoleh biaya penggantian karung sebesar Rp. 2.250 per karung (ukuran $60 \mathrm{~kg}$ ). Sebagai catatan harga karung 500 lembar ukuran $(75 \times 115) \mathrm{cm}$ adalah Rp. 1,125 juta.

Sistem pembayaran ke pedagang pengumpul adalah tunai pada saat rumput laut ditimbang. Dan beberapa pedagang pengumpul tetap diberikan modal untuk membeli rumput laut dari pembudidaya.

\section{Transportasi}

Pada lokasi-lokasi yang terisolasi dengan akses jalan menuju lokasi budidaya sangat sulit dan jalan masih tanah atau berbatu maka transportasi yang digunakan oleh pembudidaya untuk menjual hasil panen rumput laut ke pedagang pengumpul umumnya menggunakan perahu. Hal ini dilakukan jika volume rumput laut yang diangkut kurang dari satu ton. Jika volume rumput laut yang akan dibawa lebih dari 1 ton, maka alat transportasi yang dapat digunakan adalah mobil pick up atau truk.

Pada lokasi dengan akses transportasi cukup baik, maka alat transportai yang digunakan oleh pedagang pengumpul untuk menjual hasil ke pedagang besar adalah dengan menggunakan mobil pick up atau truk. Dilain pihak, alat transportasi yang digunakan oleh pedagang besar ke Surabaya adalah kapal laut. Akses pengiriman barang menuju Surabaya dilakukan melalui Pelabuhan Anggrek. Untuk pengiriman rumput laut ke Manado dilakukan dengan menggunakan truk melalui jalan darat, perjalanan ke Manado berkisar antara 7 jam sampai 10 jam.

\section{Jasa Pendukung}

Sarana produksi utama yang diperlukan untuk usaha budidaya rumput laut terdiri dari pelampung dan tali. Pelampung yang digunakan dapat berupa steroform (untuk pelampung sudut) dan botol aqua untuk pelampung tiap titik tali ris. Sedangkan tali yang digunakan berupa tali untuk tali ris, tali pelampung dan tali jangkar ukuran tali dapat dilihat pada Tabel 2. Jasa penyedia sarana produksi ini tidak seluruhnya dapat diperoleh pembudidaya di sekitar lokasi budidaya terutama di desa dan kota kecamatan. Sebagian besar sarana produksi yang harus dibeli di kota Gorontalo. Sarana produksi yang dapat dibeli di sekitar lokasi budidaya (ditingkat desa, kecamatan atau kabupaten) adalah botol bekas minuman air meneral, sedangkan tali dan pelapung sudut dengan menggunakan steroform harus di beli di kota Gorontalo.

Pada, lokasi budidaya di Kwandang Taksi Mina Bahari dapat menyediakan sarana produksi kebutuhan budidaya rumput laut sesuai pesanan, dengan demikian pembudidaya tidak perlu membeli ke kota Gorontalo. Saat ini kemampuan TMB melayani keperluan pembudidaya masih terbatas, sehingga pelayanan hanya disediakan kepada anggota TMB.

Jasa layanan perbankan umumnya hanya dimanfaatkan oleh pedagang pengumpul dan pedagang besar dalam melakukan transfer uang hasil transaksi jual beli rumput laut. Umumnya sistem pembayaran yang digunakan oleh pedagang pengumpul adalah dengan cara tunai pada saat rumput laut diterima pedagang, namun 
jika terjadi kekurangan uang kepada pedagang pengumpul dilakukan melalui jasa layanan perbankan, salah satu pedagang pengumpul yang memanfaatkan transaksi jasa perbankan ini adalah pedagang pengumpul di Desa Bajo, Kecamatan Tilamuta, Kabupaten Boalemo. Bank yang sering dmanfaatkan dalam transaksi ini adalah Bank Mandiri Cabang Gorontalo. Sampai saat ini pembudidaya rumput laut belum pernah memanfaatkan jasa perbankan untuk membiayai kegiatan usaha budidaya atau transaksi jual beli. Dari sisi perbankan usaha budidaya rumput laut ini masih dianggap belum bankable, sehingga belum layak menerima kredit perbankan.

\section{Rantai Pemasaran}

Rantai pemasaran rumput laut di Propinsi Gorontalo secara ringkas terdiri dari beberapa simpul, yaitu: pembudidaya, pedagang pengumpul (tingkat desa/ kecamatan dan Taksi Mina Bahari) serta pedagang besar.

Harga yang diterima oleh pembudidaya tergantung hubungan pembudidaya dengan pedagang pengumpul. Pembudidaya yang mempunyai ikatan dengan pedagang pengumpul melalui modal usaha atau memiliki pinjaman dari pedagang pengumpul untuk memenuhi kebutuhan hidup sehari-hari menerima harga Ro. 100,-/kg lebih rendah dari pembudidaya tanpa ikatan apapun dengan pedagang pengumpul. Pada lokasi-lokasi dimana akses transportasi sulit untuk dilalui seperti berbukit, jalan masih berupa tanah atau berbatu maka pembudidaya rumput laut umumnya mempunyai keterikatan dengan pedagang pengumpul desa. Keberadaan pedagan tersebut sangat berperan dalam mendistribusikan rumput laut hasil panen pembudidaya agar dapat dijual keluar desa.

Di Kecamatan Kwandang dan Anggrek akses pembudidaya rumput laut atau pedagang pengumpul desa lebih baik dibandingkan dengan pelaku usaha di daerah Teluk Tomini. Rasio harga yang diterima pembudidaya terhadap harga yang diterima pedagang besar sekitar 95 persen, artinya selisih harga yang diterima pembudidaya dengan harga pada pedagang besar cukup wajar. Perbedaan harga tersebut disebabkan ongkos angkut, biaya pengemasan dan jasa lainnya.

Pada wilayah dengan infrastruktur yang sulit seperti Desa Limbatihu, Desa Bubaa, Desa Bajo dan Desa Pentadu Barat di wilayah Teluk Tomini, rasio harga yang diterima pembudidaya terhadap harga yang diterima pedagang besar sekitar 82 persen, artinya selisih harga yang diterima pembudidaya dengan harga pada pedagang besar lebih besar dibandingkan pembudidaya rumput laut di Kwandang. Hal ini menunjukkan akses pedagang besar terhadap pembudidaya rumput laut akan mempengaruhi harga rumput laut. Pada lokasi dengan akses yang sulit, maka pembudidaya akan memperoleh harga rumput laut lebih rendah dari pembudidaya dengan akses yang baik.

Secara ringkas rantai pemasaran pada dua tipikal infratruktur di Gorontalo : daerah terisolasi (wilayah Teluk Tomini) dan tidak terisolasi (wilayah Laut Sulawesi) dapat dilihat pada tampilan Gambar 1.

\section{Persfektif Klaster Rumput Laut Gorontalo}

\section{Prinsip Klaster}

Sebagai gambaran tidak semua klaster yang terdapat di Indonesia dapat berjalan dengan sempurna Abdullah (2000). Seperti yang dikemukakan oleh Nasution (2006) beberapa klaster setelah diimplemetasikan dapat beroperasi dengan baik, namun sebagian klaster terlihat tidak dapat beroperasi seperti yang diharapkan. Kegagalan berfungsinya klaster tersebut menurut Humphrey dan Schmitz (1995), karena pembentukan klaster tersebut kurang mempertimbangkan prinsip: customer oriented, collective dan cumulative. Keberhasilan klaster yang terdapat di beberapa daerah di Indonesia, ditentukan sekurangnya oleh 3 prinsip tersebut.

Pengembangan klaster yang berorientasi pada consumer oriented 
dimaksudkan untuk menyesuaikan hasil produksi klaster dengan permintaan pasar, dengan demikian unit usaha yang terdapat dalam klaster tidak menjalankan usahanya berdasarkan supply oriented, sehingga unit usaha tersebut dapat berkompetisi untuk meperoleh pangsa pasar dengan menentukan cara (teknologi dan jaringan kerja) dalam memenuhi permintaan pasar sesuai dengan standar yang diinginkan pembeli.

Klaster yang dikembangkan merupakan

DAERAH TERISOLASI / REMOTE AREA

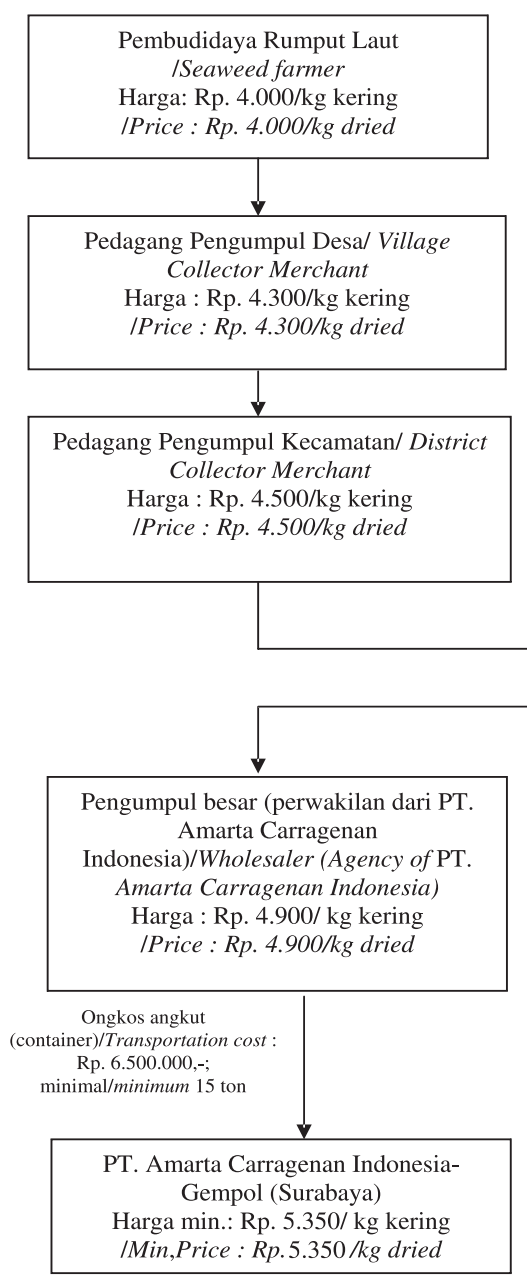

kumpulan dari unit-unit usaha yang secara kolektif dapat memperbaiki kinerja dari klaster. Kumpulan dari unit usaha yang mempunyai orientasi yang sama ini dapat mengurangi berbagai biaya transaksi dalam distribusi barang. Sebagai contoh kolektivitas ini sangat diperlukan jika pasar meminta pasokan rumput laut dalam jumlah besar, jumlah yang demikian tidak dapat dipenuhi oleh satu unit usaha kecuali dipenuhi oleh beberapa unit usaha didalam klaster tersebut. Dengan kolektif seperti ini, unit-unit usaha tersebut
DAERAH TIDAK TERISOLASI/ NON REMOTE AREA

Pembudidaya Rumput Laut ISeaweed farmer

Harga: Rp. 4.650/kg kering /Price : Rp. $4.650 / \mathrm{kg}$ dried

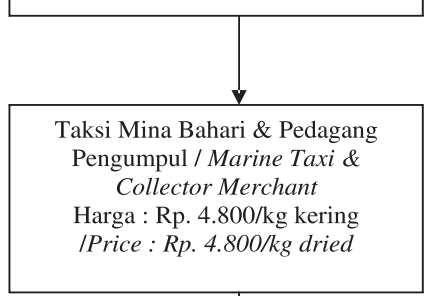

Gambar 1. Rantai Pemasaran Rumput Laut di Propinsi Gorontalo, 2007 Figure 1. Seaweed Marketing Chain in Gorontalo Province, 2007. 
Unit usaha dalam klaster yang telah berkembang secara kolektif dapat mendorong peningkatan akumulasi kinerja klaster tanpa tergantung dari upaya (intervensi) dari luar. Walaupun pada awalnya untuk membangun klaster diperlukan intervensi dari luar, namun tujuan dari intervensi ini adalah untuk memperbaiki kapabilitas dari masing-masing unit usaha untuk mendorong terjadinya hubungan usaha yang sinergis antara seluruh unit usaha secara kumulatif dengan pasar secara independen.

\section{Bentuk Klaster Rumput Laut}

Sesuai dengan hasil identifikasi dilokasi penelitian maka, komponen-komponen pembentuk klaster rumput laut di Provinsi Gorontalo dapat dikelompokkan sebagai berikut:

1. Kelompok unit usaha yang mendukung proses produksi, unit usaha ini terdiri dari: usaha pembibitan rumput laut dan usaha penyedia sarana produksi.

2. Kelompok unit usaha proses produksi rumput laut, unit usaha ini terdiri dari: usaha budidaya rumput laut.

3. Kelompok unit usaha jasa distribusi barang, unit usaha ini terdiri dari unit usaha perdagangan dan transportasi barang.

4. Kelompok jasa pendukung, yang terdiri dari lembaga keuangan, dan pemerintah.

Unit usaha pembentuk klaster tersebut dalam menjalankan usahanya harus berfungsi sinergi satu dengan lainnya dengan menempatkan diri secara proporsional pada posisi masing-masing. Fungsi itu dibangun berdasarkan hubungan kedepan (forward lingkages), dan hubungan kebelakang (backward lingkages) dari masing masing unit usaha.

Pada industri rumput laut di Provinsi Gorontalo, pedagang besar adalah yang menjadi core utama yang menggerakkan pengembangan rumput laut di wilayah tersebut. Hal ini disebabkan karena industri pengolah rumput laut belum terdapat di wilayah ini. Bentuk hubungan kedepan dan kebelakang dari pedagang besar dalam klaster rumput laut Gorontalo dapat diperhatikan pada Gambar 2.

Hubungan kebelakang pedagang besar tergantung pada pedagang pengumpul desa dan kecamatan, pembudidaya rumput laut, taksi Mina Bahari, Sementara keterkaitan kedepan dari pedagang rumput laut tergantung pada jasa transportasi darat, laut, PT. ACI dan PT. Sumber Nelayan serta jasa pendukung (perbankan dan unit kerja pemerintah). Saat ini keterkaitan kedepan dan kebelakang dari klaster tersebut belum tertata dengan baik, hubungan kebelakang dan kedepan pedagang besar dengan unit usaha pendukungnya telah dibangun secara alami dalam bentuk integrasi vertikal. Artinya setiap unit usaha yang terlibat dalam bisnis rumput laut tersebut saling membutuhkan. Hubungan yang demikian akan dapat mempengaruhi kinerja unit usaha kecil dengan modal yang terbatas. Jika pemerintah akan melakukan upaya untuk mendirikan industri pengolahan produk setengah jadi dalam bentuk Semi Refines Carragenan (SRC), maka upaya tersebut dapat merusak tatanan rantai pemasaran yang telah dibangun oleh pedagang besar, dan akan terjadi konflik dalam bisnis rumput laut.

Keberhasilan tersebut tergantung kemampuan dari industri SRC dalam memobilisasi dana untuk membeli rumput laut kering dan membiayai operasional industri tersebut. Sebagai gambaran pedagang besar yang tidak mempunyai pabrik pengolahan di Kwandang, rata-rata dalam satu hari harus menyediakan dana tunai untuk membeli rumput laut sekitar Rp. 20 juta - Rp. 25 juta untuk mendukung pedagang-pedagang pengumpul yang membeli rumput laut di berbagai lokasi di Gorontalo. Dana tunai tersebut akan kembali lagi kepada pedagang besar dalam seminggu. Hal itu berarti pedagang besar tersebut sekurangkurangnya harus menyediakan dana tunai selama seminggu sekitar Rp. 140 juta hingga 175 juta untuk membeli rumput laut kering. 


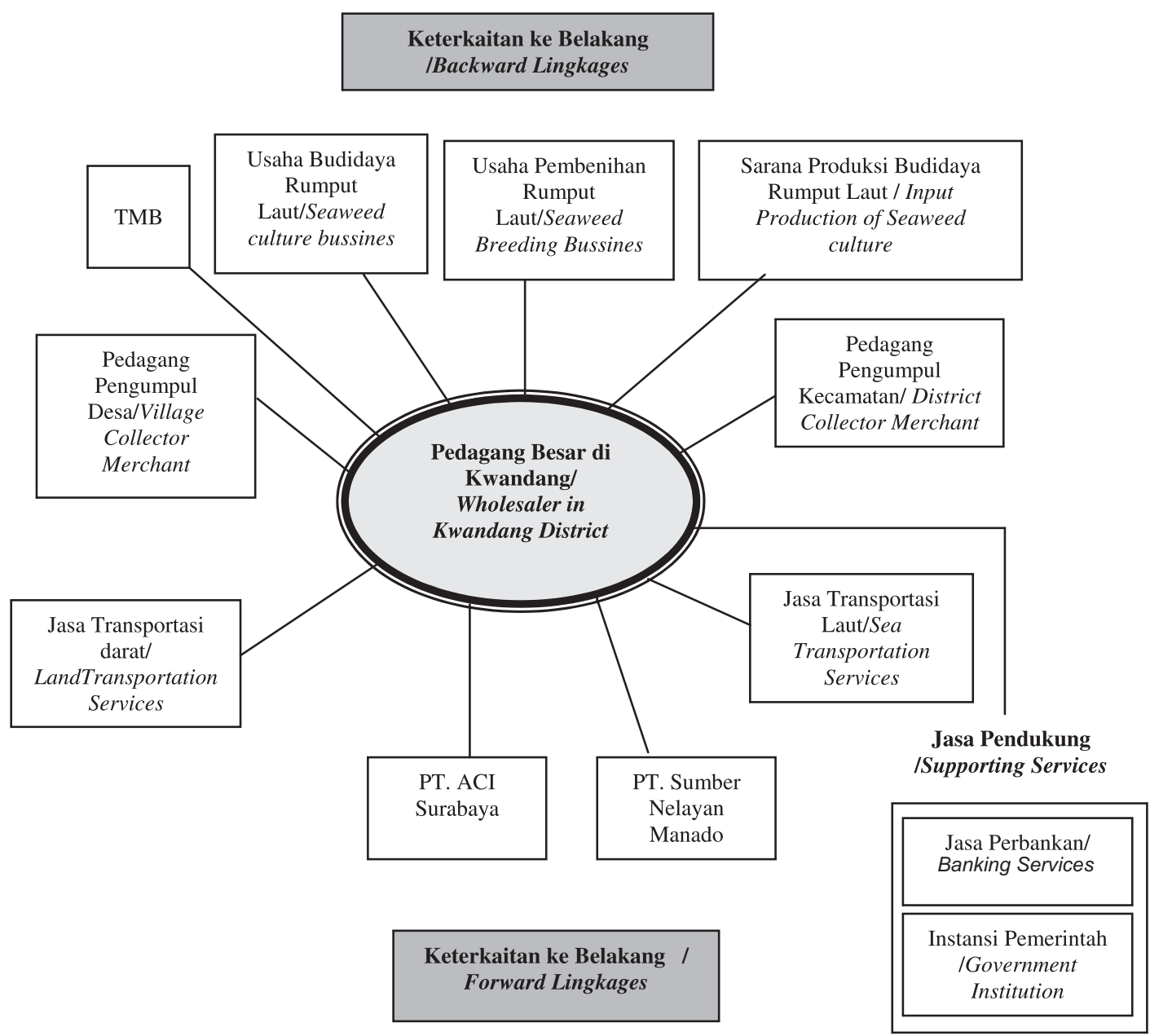

Gambar 2. Keterkaitan Kedepan dan Kebelakang Klaster Rumput Laut di Provinsi Gorontalo Figure 2. Forward and Backward Lingkages of The Seaweed Cluster in Gorontalo.

Demikian juga memfungsikan TMB sebagai pedagang besar atau pengelola industri SRC dengan dukungan dana dari pemerintah dapat berakibat pada rendahnya target yang dicapai, karena TMB tersebut tidak mempunyai rantai untuk memasarkan produk yang dibelinya ke luar Gorontalo. Dengan demikian TMB tetap akan menjual rumput laut tersebut kepada pedagang besar yang ada di Kwandang.

Terkait dengan pengembangan rumput laut maka dalam tatanan klaster tersebut, maka jika pemerintah akan mengembangkan rumput laut maka TMB lebih baik diarahkan untuk membangun dan mengkoordinasikan kegiatan yang berbasis pembibitan rumput laut dan penyediaan sarana produksi untuk pembudidaya rumput laut. Hal ini terkait dengan kesulitan bibit rumput laut yang kerap disampaikan oleh pembudidaya. Selanjutnya dalam jangka panjang pemerintah mendorong melalui kebijakan pemberian insentif kepada pedagang besar untuk membangun industri SRC di Gorontalo. 


\section{KESIMPULAN DAN REKOMENDASI KEBIJAKAN}

Komponen-komponen pembentuk klaster rumput laut telah terbentuk secara alami di Gorontalo. Komponen-komponen tersebut terdiri dari jenis usaha pendukung proses produksi, jenis usaha proses produksi rumput laut, jenis usaha perdagangan dan distribusi, jenis usaha jasa pendukung. Saat ini komponen-komponen tersebut belum tertata dengan baik, sehingga kinerja dari industri rumput laut di Gorontalo belum optimal.

Terkait dengan upaya memfungsikan klaster rumput laut, maka terdapat tiga prinsip yang perlu dipertimbangkan agar klaster tersebut berfungsi secara optimal, pertama, unit usaha dalam klaster rumput laut harus berorientasi pada permintaan konsumen (consumer oriented), klaster harus bersifat kolektif, dan klaster dapat memperbaiki daya saing secara kumulatif.

Disamping itu untuk menumbuhkan klaster, diperlukan tiga tahapan dalam pengembangan klaster, tahapan pertama adalah tahap persiapan yang dikenal sebagai tahap pembangunan klaster (Build B), tahap kedua adalah tahap konsolidasi disebut sebagai tahap operasi (Operated- O), dan tahap ketiga adalah tahap independensi beroperasinya (Transfer T) klaster.

Pengembangan klaster rumput laut di Gorontalo memerlukan pembenahan, karena terdapat daerah produksi yang infrastrukturnya sangat sulit, sehingga berpotensi terjadi asimetris informasi harga bahan baku rumput laut kering dibutuhkan pasar. Asimetris informasi tersebut saat ini belum mempengaruhi kinerja pembudidaya.

Dengan demikian pengembangan klaster rumput laut di Gorontalo harus memperhatikan keterkaitan kebelakang dan keterkaitan kedepan dari core bisnis rumput laut. Core yang menghela bisnis rumput laut di Gorontalo saat ini adalah pedagang besar. Oleh sebab itu untuk membangun industri pengolahan didaerah ini, keikutsertaan pedagang besar perlu dipertimbangkan. Pedagang besar tersebut perlu diberi insentif agar mereka mau membangun industri pengolahan rumput laut (chip atau powder) di Gorontalo. Disamping itu TMB dapat diarahkan untuk membangun dan mengkoordinasikan usaha pembibitan rumput laut dan sarana yang diperlukan oleh pembudidaya rumput laut, sehingga keberadaannya mempunyai arti penting dalam pengembangan rumput laut di Gorontalo.

\section{DAFTAR PUSTAKA}

Abdullah P. 2000. Daya Saing Daerah. BPFE, Jogyakarta.

Direktorat Pengembangan Kawasan Khusus dan Tertinggal, 2004. Kajian Strategi Pengembangan Kawasan dalam Rangka Mendukung Akselerasi Peningkatan Daya Saing Daerah. Bapenas. Jakarta.

Dinas Perikanan dan Kelautan Propinsi Gorontalo. 2006. Pengembangan Usaha Budidaya Rumput Laut Melalui Gerakan Menanam Rumput Laut (Gemar Laut). Gorontalo.

Humprey. J and H. Schmitz, 1995. Principle for Promoting Clusters and Networks of SMEs. UNIDO..

JICA. 2003. The Study on Strenghthening Capacity of SME Cluster in Indonesia. KRI International Corp. (unpublish report).

Kuncoro, Mudrajat, Sumarno dan S. Bambang. 2003. Indonesia's Clove Cigaret Industry, Cluster Analysis. $5^{\text {th }}$ IRCA Conference.

Nasution A.H. 2006. Pengembangan Klaster Jawa Timur, Bagaimana seharusnya? www.its.ac.id/berita. php?nomer=2443. ITS-Surabaya. 20 Juli 2007.

Porter. M.E 1990. Keunggulan Bersaing, Menciptakan dan Mempertahankan Kinerja Unggul. Harvard Business Review. (Terjemahan). 